Casero-Ripollés, A. \& López-Rabadán, P. (2017). With or without you: The role of personal affinity in relationships between journalists and politicians in Spain. Journalism, DOI: $10.1177 / 1464884916688288$.

http://journals.sagepub.com/doi/full/10.1177/1464884916688288

\title{
WITH OR WITHOUT YOU: THE ROLE OF PERSONAL AFFINITY IN RELATIONSHIPS BETWEEN JOURNALISTS AND POLITICIANS IN SPAIN
}

\author{
Andreu Casero-Ripollés ${ }^{1}$ \\ Universitat Jaume I de Castelló (Spain) \\ Pablo López-Rabadán \\ Universitat Jaume I de Castelló (Spain)
}

\begin{abstract}
Informal relationships between journalists and politicians have a strategic function in the process of news making. The aim of this article is to analyse the role of personal affinity between the media and politicians in Spain. This study focuses on the following three specific issues: self-definition of their interactions, degree of influence, and main professional risks and benefits detected. The methodology is based on 45 in-depth interviews (22 journalists, 16 politicians, and 7 spin-doctors). The novelty of this article is the analysis of not only the views of journalists but also the perceptions of the political actors. The results demonstrate the relevance and influence of affinity relationships between journalists and politicians. The two types of actors are highlighted as main beneficiaries of direct access to high-quality information sources or the ability to achieve positive news coverage. However, certain risks are also linked to these informal relationships.
\end{abstract}

KEYWORDS: Political journalism, journalistic role performance, political communication, personal affinity, political actors, professional role, informal relationships, Spain

\section{Introduction}

The interactions between journalists and politicians have been a prominent theme in research on political communication since the 1960s. Researchers' interest in this issue has increased rather than decreased in recent years (Albæk et al., 2014; Esser, Strömbäck and De Vreese, 2012). The strategic nature of this relationship, its complexity and its influence in shaping media coverage and news content explain this fact (Cook, 2005). Power relationships between journalists and politicians determine the journalistic role performance (Mellado, 2014). Despite the significant attention on this issue, there remain little-studied aspects of the interaction between these actors. One is the role and influence of personal factors, specifically affinity or closeness, within the relationships and contacts between journalists and politicians.

Political information is a key element in the functioning of a democratic system because of its ability to set the agenda, stimulate public debate, shape public opinion and encourage political participation, etc. (Albæk et al., 2014). Therefore, the processes

\footnotetext{
${ }^{1}$ Corresponding author: Andreu Casero-Ripollés, Departament de Ciències de la Comunicació, Facultat de Ciències Humanes i Socials, Universitat Jaume I de Castelló, Av. Vicent Sos Baynat, s/n 12071 Castelló de la Plana, Espanya. Email: casero@uji.es
} 
leading to its development have an important role. One mechanism that decisively shapes political news is the relationship established between journalists and politicians. This interaction directly affects the media's coverage of politics, determining both the construction of the agenda and the frame of the news. Increased exchanges between journalists and politicians can be used as a first-order indicator to gauge the political role of the media (Cook, 2005). The study of the interactions between these actors becomes, in this view, a relevant research topic.

Most of the academic literature has focused on analysing the influence of the relationships that exist between journalists and politicians in the process of news making. Thus, the dialectic between cooperation and competition and between tension and conflict has been the focus of most of this research. Few studies have focused on the informal and personal interactions that occur between these actors. The novelty of this article is its focus on studying the role of personal affinity in the relationships between journalists and politicians, which is a subject that has not been fully explored. There is only limited research associated with Northern European countries, including those within the democratic corporatist model, that has addressed this issue specifically (Van Aelst and Aalberg 2011) or indirectly (Larsson 2002). Therefore, more research is needed to explore this phenomenon and determine its effects.

The aim of this paper is to fill this gap in the literature by studying the impact of personal affinity on relationships between journalists and politicians in the current context. We define these affinity contacts as the set of informal relationships and personal interactions between journalists and political actors (e.g., spontaneous conversations, confidences, extended telephone calls, lunches or friendly meetings) that have a direct influence on the process of news making.

Employing a methodology based on the application of a qualitative research technique, in-depth interviews, and using a sample of 45 subjects of several different profiles (journalists, politicians and spin-doctors), the following three aspects are discussed: the role of personal closeness in the interaction; the interaction's actual influence on the process of agenda building and news making; and the interaction's consequences from the point of view of risks and benefits for both journalism and democracy. Specifically, this study focuses on an analysis of political journalism in Spain. Spain is included in the polarized pluralist model (Hallin and Mancini, 2004), which is characterized by late democratization, a strong presence of political parties in political life, a lower degree of professionalism among journalists, strong state intervention in the media, information oriented towards the interests of political elites and opinionative comment, and finally a high level of political parallelism. Specifically, this strong politicization is one of Spain's main defining characteristics (Casero-Ripollés, 2012; Van Dalen, 2012; Van Dalen, De Vreese and Albæk, 2012; Sampedro and Seoane, 2008; Casero-Ripollés, García-Santamaría and Fernández-Beaumont, 2015).

\section{The complex interactions between journalism and politics within mediatization dynamics}

The current framework of relationships between journalists and political actors is the mediatization of politics (Mazzoleni and Schutz, 1999). From this perspective, the media is the stage where politics is presented to society. Thus, it becomes the main source of information about politics and the main channel of communication between political actors and citizens (Strömbäck and Van Aelst, 2013). At the same time, journalists play a key role as players actively involved in the political debate. This role places them in a central position in contemporary societies. Policy issues are conveyed primarily through the media. The media impose their own logic and specific rules (Altheide and Snow, 1979). Political actors must adapt to the "media logic" and interact with journalists to enjoy media 
coverage and the social visibility that this entails. However, other reactions are possible. Some political parties, such as Podemos in Spain, have driven a mediatization ranging from politics to the media due to the digital landscape and social media, generating an influence of the former over the latter. Thus, no media factors can activate and also boost mediatization, which is based on a two-way street conception and improves the mediacentric dominant view (Casero-Ripollés, Feenstra and Tormey, 2016). In this view, the media have become a natural part of politics, and this influences how politicians think and act (Davis, 2007).

Mediatization involves a high degree of proximity between journalists and politicians who share spaces. Both players share the same networks and the same physical locations. This sharing creates mutual influence between them (Strömbäck and Esser, 2014). This influence frequently causes mutual dependence (Gans, 1979; Blumler and Gurevitch, 1995). Journalists need politicians as potential sources of information to produce their news. At the same time, politicians need journalists to spread their messages, publicize their ideas, promote their public images and gain the support of the citizens for their policies (Van Aelst et al., 2008). Both actors seek mutual access in a dynamic in which availability appears to be a key element. In this context, these actors continuously adapt their behaviours to the expected behaviours of their counterparts (Albæk et al., 2014).

This mutual dependence and proximity keep the relationship between journalists and politicians shifting between agreement and conflict (Nimmo, 1964). This shift may be driven by pragmatism because both actors seek mutual benefit and have things to gain. Thus, there is resource-sharing and interdependence dynamics. This relationship can be described as symbiotic (Delli Carpini, 1994; Gans, 2003). However, the relationship may also be controversial. The defence of opposing ideological positions or the discovery of conflicting interests can lead to confrontation. Sometimes, both the journalists and politicians seek mutual access to not only achieve the noted benefits but also seek control of the relationship. A tug of war is thus established wherein politicians attempt to manage the news to offer the best image of themselves and their proposals, while journalists attempt to manage politicians to extract desired information (Gans, 1979). Consequently, tension is inherent in this interaction (Blumler and Gurevitch, 1995). These factors generate distrust in the relationship between journalists and politicians.

Recent studies state that the simultaneously combined interaction between these actors results in mutual dependence requiring them to be in contact, with little trust in each other (Davis, 2007; Van Aelst and Aalberg, 2011). This dialectic between trust and distrust affects the patterns of the relationships established between journalists and politicians. They develop interactions within a constant negotiation characterized by dynamism and flexibility (Casero-Ripollés, 2008). Consequently, alliances and tensions between these two actors are redefined depending on multiple factors, such as political context and editorial and media ownership (Larsson, 2002; Sampedro and Seoane, 2008). Love and hate are natural parts of this relationship. Therefore, metaphors characterizing such relationships range from the recent qualifier schizophrenic (Van Aelst and Aalberg, 2011) to the classic that references a dance, specifically the tango (Gans, 1979) to images likening journalists and politicians to strange bedfellows (Rosenstiel, 1993).

\section{Personal affinity as a conditioning factor of the relationship between journalists and politicians}

A key element of the interactions between journalists and politicians is the role of personal factors in this relationship. In this sense, the literature identifies the following two major forms of relationships: formal and informal (Mancini, 1993). This latest project 
involved contact behind the scenes and outside structures established by professionalization (e.g., confidential telephone calls or friendly meetings) as a preferred form of interaction between journalists and politicians. The sharing of physical spaces is found on a daily basis in the informal relationships because the frequency of this type of more personal contact is the bond that develops information relationships. Thus, both sides are socialized into the culture of the other (Larsson, 2002) and share the same social world. This stabilizes the interdependencies between them (Neveu, 2002). In these cases, personal aspects and affinity underlie the relationship. Within this framework, personal closeness becomes a key element that determines and regulates the interaction. This situates the relationship between journalists and politicians inside a model of cooperation, and a context of maximum closeness is imposed, involving pragmatism, symbiosis and mutual dependence.

Two prerequisites for the existence of an informal relationship based on affinity are, on the one hand, trust, and, on the other hand, the need for equality and balance between the actors involved (Larsson, 2002). Journalists and politicians should respect each other and maintain that respect based on their personal affinities because, otherwise, distrust, suspicion and cynicism will arise (Brants et al. 2010; Van Aelst and Aalberg, 2011). Other factors that reduce the role of personal closeness and enhance political cynicism are the pressures on the journalists, on the one hand, and professionalization and spin-doctors, on the other (Van Dalen et al., 2011). Press spokesmen, spin-doctors or communication officers seek to impose a type of indirect interaction based on formal relations that reduces the importance of personal affinity (Van Aelst and Aalberg, 2011). Additionally, countries with liberal political media systems, where the media and politicians are observed as adversaries, and countries with high levels of clientelism and politicization of the media that dominate and control the pressures on journalists are more susceptible to relationships developing between journalists and politicians that are disharmonious and cynical (Maurer and Pfetsch, 2014).

The benefits of cooperation based on affinity are diverse. For journalists, it means having quick and easy access to sources of political information that can be considered highly reliable based on trust. The media can have greater access to what occurs out of the public view, including access to details about politicians' private lives and policy. Meanwhile, politicians find it easier to communicate their messages to the public through the media, which are accessed preferentially. Politicians are also more likely to receive favourable coverage in these cases. Additionally, journalists can advise on how to behave for the media because they have a great deal of information about the political process and understand the logic of the media (Davis, 2007).

The analysis of personal affinities between journalists and politicians allows studying the media's level of influence on the boundaries of politics and vice versa. The media can have the power to set the public agenda, focusing public attention in an agenda-setting dynamic (McCombs et al., 2011; Walgrave, 2008), and to set the political agenda, determining the decision-making process (Lang and Lang, 1981; Van Aelst et al., 2008). However, political actors can also condition the news media, orienting their agenda and framework and thus managing to dominate the process of opinion making (Sellers, 2010; Wolsfeld, 2011; Hanitzsch and Mellado, 2011; Casero-Ripollés \& López-Rabadán, 2014). To achieve this goal, we can hypothesize that informal relationships and affinity can facilitate the influence of political actors in the process of agenda building.

Personal affinities act on the relationship's media-sources, providing politicians access to the agenda and media frame (Delli Carpini, 1994). Thus, the affinity acts as a lubricating factor for news management (Tedesco, 2011).

However, the cooperative model, which involves the dominance of personal affinity at the heart of the relationship between journalists and politicians, also creates risks. The main danger is that this relationship pattern is linked to political parallelism and the 
development of the phenomenon of political control of the media. Closeness between journalists and politicians can make it difficult for the media to fulfil its normative function of scrutinizing political power (Casero-Ripollés et al., 2014). A strong affinity between these two actors could jeopardize journalists' political independence (Van Aelst and Aalberg, 2011). These objections do not affect politicians. However, the resulting proximity may make it difficult for politicians to maintain secrecy and can facilitate information leaks to journalists.

Alternatively, formal relations imply that personal sympathy stops playing a prominent role in the interaction between journalists and politicians. Intimate and informal contacts are reduced or eliminated, and personal and direct interaction between politicians and journalists is less frequent and fluid. One of the normative prescriptions of this model is the need to establish distance between journalists and politicians to preserve journalistic independence and avoid political influence on media coverage due to personal factors. In this framework, the mechanisms of formal contact comprise press conferences, informational releases and focused interviews, leaving little room for personal contact out of the public view. Journalists see their degree of initiative reduced under this relationship model and expect that political actors are more likely to condition the media agenda (Berganza et al., 2010).

\section{Method}

This research aims at studying personal affinity and informal relationships between journalists and politicians based on their own perceptions. To achieve this aim, the following specific objectives are proposed:

01. Review the role of affinity in professional relationships between journalists and political actors.

O2. Assess the degree of influence of affinity on the process of information production and construction of the media agenda.

O3. Identify the main consequences of affinity relationships, understood as potential risks and/or benefits, to the operation of the media industry and the democratic system.

Coordinated with each of these objectives, we propose the following hypotheses:

$\mathrm{H} 1$. Personal affinity and informal relationships play a significant role in the professional interaction between journalists and politicians.

$\mathrm{H}$ 2. Personal closeness and informal interactions have a significant influence on the professional dynamics of journalists and political actors and, therefore, on the conduct of public discourse.

H3. The benefits of affinity for journalists consist of expanded access to political information that increases their productivity and competitiveness. Conversely, politicians receive more favourable media coverage, greater capacity to frame the news and reinforcement of social legitimacy.

H4. Informal relationships between journalists and politicians tend to take place in the context of a power imbalance favouring the latter. This poses a significant risk to journalists' maintenance of critical and professional independence.

To analyse informal relationships between journalists and politicians, we have opted for the qualitative research technique of in-depth interviews. The complexity of the subject matter, with a significant number of variables and dimensions and the need to ensure confidentiality, favour this technique for a detailed investigation of the interaction between professional journalists and political actors. Furthermore, this study provides the following two important methodological innovations: The analysis focuses on the perceptions of the 
protagonists and, within those perceptions, a direct view of not only journalists but also of political actors is provided. This is an important original contribution that this research makes to the literature.

The sample comprises 45 interviews conducted with 22 journalists and 23 political actors. Specifically, in this second group of political actors, we interviewed 16 politicians and 7 spin-doctors. The selection criteria were strategic and twofold as follows: first, professional relevance within the sector; second, an attempt at balance in the sample among different media, hierarchical levels and geographical locations. Regarding journalists, there was a balanced selection of media (press, radio, television and Internet) and professional levels (managers, middle managers and editors). Regarding political actors, we included institutional representatives at different levels of government (national, regional and local) and representatives of opposing parties. The interviews were prepared from a questionnaire structured into four blocks, reviewing various issues concerning the interaction between journalists and politicians, including one specific block of six questions that focused on their mutual perceptions. The questions included the following three aspects: the role of personal closeness in the interaction; the actual influence on the processes of agenda building and news making; and the consequences of those affinities in terms of their risks and benefits for both journalism and democracy. The interviews were conducted face-to-face in three politically relevant regions in Spain (Madrid, Valencia and Catalonia) between January and May 2012; each interview had a duration of 45 to 70 minutes.

\section{Results}

\subsection{Current definition of personal affinity between journalists and politicians}

Despite the professionalization process experienced in the field of political communication in recent decades, the results show two key ideas about the validity and relevance of affinity and informal relationships between journalists and political actors. The first is the recognition (partially explicit) of the existence of these relationships. The second is the description of several professional factors that explain their importance.

\section{Recognition through a dual discourse}

First, regarding the definition of personal affinity between journalists and politicians, we detect the existence of a highly significant double discourse. On the one hand, we find a main discourse, primarily between the two types of actors, which stresses the almost exclusive preponderance of formal relationships. In this sense, although there may be certain cases of closeness, those who use this discourse believe that interactions mainly occur through professional channels.

Although it can sometimes be friendly, [the relationship] is primarily professional. (Journalist 1)

I think overall the relationship is professional, but that does not mean that you could [not] have a personal relationship with certain journalists. (Politician 7)

Conversely, an alternative discourse acknowledges, in a more realistic and enlightened way the existence of close and regular informal relationships between journalists and politicians. Many actors consider these informal relationships almost inevitable within the shared professional context. 
In some cases, it is strictly business, and, in other cases and after a while, it is clear that there someone who you like better or worse and who treats you better or worse. Personal affinities have importance. (Politician 16)

In this regard, we find a significant difference in the interpretations by the two groups of their informal relationships. Journalists see these relationships as problematic partly because they believe that excessive closeness to political actors can affect their professional activities.

I think they should be strictly professional, but they are (actually) too close and friendly. (Journalist 5)

Meanwhile, politicians are less troubled in their valuations; they recognize their habitual proximity to reporters and generally consider it positive if it is established with a correct differentiation between personal and professional fields.

I think it is a friendly and close relationship. Outside of what journalism is, the act itself (such as the interview) the relationship is quite close. (Politician 9)

In summary, analysis of the interviews makes clear that professionalization of the sector has failed to significantly limit by protocol filters (e.g., press conferences or management access to interviews) the existence of informal relationships between journalists and politicians. In fact, it has only achieved the following limited and superficial result: This type of informal interaction is now managed more discreetly and is referred to in euphemistic discourse.

\section{Existence of a propitious professional context}

Second, respondents note two professional factors largely explaining the importance and relevance of informal relationships between journalists and politicians. The first is the high level of interest and mutual need that determines their professional interactions. In this sense, both political actors and the media are aware of the important role that each plays in the development of their professional activities. Both groups emphasize the synergistic nature of their relationships and the importance of maintaining a high level of respect and cordiality to achieve their goals.

It is necessary and essential for both. Without access to the media, politicians are nothing, and without good sources among politicians, journalists cannot fulfil their obligation to report. The important thing is to have clear red lines respected scrupulously by both parties. (Journalist 8 )

A second key factor is the frequent need to share locations and physical spaces. The professional routines of both groups (e.g., conducting press conferences and interviews, making specific statements) involve constant interaction between the two groups, at times in close proximity and with great intensity. In the long term, this physical proximity inevitable creates informal relationships of all types, sometimes characterized by greater affinity and sympathy and sometimes antipathy for others-or even conflict.

So overall it is a professional relationship, but obviously, when you're working with someone every day, you can always produce a much closer relationship with certain journalists. (Politician 10) 
Altogether, the physical proximity of the dynamics of work and, above all, the existence of strong synergies have generated a significant consequence as follows: Journalists and politicians alternate between naturally formal and informal relationships within a highly interactive professional context (Table 1).

Table 1. Summary of the results of defining affinity relationships between journalists and political actors

\begin{tabular}{|c|c|}
\hline \multicolumn{2}{|c|}{ Main perceptions detected } \\
\hline $\begin{array}{l}\text { 1. Presence of a dual defining } \\
\text { discourse }\end{array}$ & $\begin{array}{l}\text { - Dominant discourse, preponderance of formal } \\
\text { relations } \\
\text { - Emergence of an alternative discourse that also } \\
\text { recognizes regularity and closeness in informal } \\
\text { relations }\end{array}$ \\
\hline $\begin{array}{l}\text { 2. Disparate assessments of } \\
\text { informal relations }\end{array}$ & $\begin{array}{l}\text { - Journalists: viewed relations as partially } \\
\text { problematic for their professional activities } \\
\text { - Politicians: viewed relations as less problematic } \\
\text { and overall positive }\end{array}$ \\
\hline $\begin{array}{l}\text { 3. Existence of a favourable } \\
\text { professional context, based on two } \\
\text { factors }\end{array}$ & $\begin{array}{l}\text { - Synergistic nature of their relationships } \\
\text { - Frequent need to share locations and physical } \\
\text { spaces }\end{array}$ \\
\hline
\end{tabular}

\subsection{High perceived influence of informal relationships}

Regarding the overall assessment of the informal relationships between journalists and politicians, the analysis of the interviews provides a clear diagnosis. Both groups recognize the professional influence of these relationships, and both indicate a number of factors that can exacerbate or significantly limit them. In the sample, only a very small proportion of journalists consider their influence scarce or non-existent.

\section{The debate about the influence of personal affinity and its determinants}

Regarding the degree of influence of informal relationships, the results clearly identify two positions (Table 2). A majority explicitly consider them to have a strong or very strong influence. A second minority group is observed to believe that this influence is limited by some factors or that it is only relevant for certain subjects or actors.

Among those who associate great influence with these relationships, we distinguish different views between journalists and politicians; for the former, overall, this influence is a potential professional problem. However, the latter consider the influence a natural consequence of their relationships. In this sense, journalists claim that these informal relationships often arise as a dynamic exchange of favours that is difficult to escape.

While we may not want to admit it or we do implicitly, it is noted that there is a relationship, a 'quid pro quo': you give me the news-just me (if interested, of course)-and I treat you better than another politician that has not given me anything. (Journalist 9) 
However, politicians display a more favourable and pragmatic perspective on their informal interactions: They recognize this influence as an important tool to achieve better coverage if it is linked to the development of relationships based on trust and sincerity.

Friendship is a key factor. If there is affinity, there is trust and mutual loyalty. Thus, the politician will be more honest in their opinions, and the reporter will also be more sincere in what will be reflected in the media. (Politician 14)

We also find a second group of journalists and politicians, a minority within the sample, who assert that personal relationships have a limited influence on their work. Under this view, personal affinity sometimes serves as a mere mechanism to achieve, on special occasions, more favourable media coverage. Additionally, this group specifies two factors that limit the influence of affinity and informal relationships. The first is the basic principle of professional ethics as related to quality production routines, such as providing contrasting information from various sources.

What makes you a credible and good professional is the method and attitude, not your affinities and sympathies, but sometimes that happens because sometimes [a relationship] carries more sympathy, friendship, political ideology or loyalty than the professionalism. (Journalist 19)

Second, some political actors maintain that their editorial line and business interests are more decisive factors in regard to conditioning the news agenda than are personal relationships or affinity with journalists.

Personal contact can persuade in some respects, filing some edges, but in the end what counts is the orientation, the editorial line of each medium and enterprise. (Politician 12)

Table 2. Summary of results on the professional influence of their informal relations

\begin{tabular}{|l|l|}
\hline \multicolumn{3}{|c|}{ Main perceptions detected } \\
\hline $\begin{array}{l}\text { 1. Debate articulated from two } \\
\text { positions }\end{array}$ & $\begin{array}{l}\text { - Majority group: considers relationships to have } \\
\text { a strong or very strong influence, as a result of a } \\
\text { dynamic of mutual "exchange of favours" }\end{array}$ \\
\cline { 2 - 2 } & $\begin{array}{l}\text { - Minority group: considers relationships to have } \\
\text { limited influence due to factors such as } \\
\text { "professional ethics" and "the contrast between } \\
\text { different sources" }\end{array}$ \\
\hline
\end{tabular}

\subsection{Main risks and benefits of personal affinities}

Regarding the specific consequences of their informal relationships, both journalists and political actors recognize important benefits but also some risks to which they are exposed in these interactions. In keeping with the centrality and influence of affinity indicated in previous sections, very few actors ignore the professional benefits or see them as a minor issue. 


\section{Balance of Power? Key factor in assessing the benefits of affinity}

Overall, both groups insist on respect and balance as key factors that determine decisively the development of their informal relationships, allowing them to tap synergies and limiting potential abuses of power. However, if these relationships are not developed within a framework of strict balance and professional respect, they can become tools of control and professional pressure, with a significant risk of polluting the information. Considering these dynamics, the next sections will summarize the main benefits and risks identified in the analysis of the interviews (Table 3).

\section{Benefits related to balance in informal relationships}

Regarding the benefits of personal closeness, each affected group highlights some specific issues. For journalists, a fluid relationship with politicians is perceived as a very useful tool to glean exclusive information that they would never receive through a press office, information that serves to improve their work and differentiate it from that of competitors, adding an extra competitiveness factor.

Benefits are always immediate because from this fluidity, this affinity in the relationship, it is assumed that the politician is going to provide information, documents or statements exclusively. (Journalist 9)

Additionally, some journalists note a second benefit as follows: Personal access to political sources allows better compliance with several key journalistic functions. In particular, obtaining higher-quality information enriches public debate and allows closer monitoring of political management, ultimately leading to increased transparency in the functioning of the democratic system.

In principle, the benefit should be greater transparency and democratic control of power. (Journalist 17)

Likewise, there is among political actors a clear perception of the main benefit from a personal affinity with reporters. They understand these informal relations as a key resource to increase and improve the type of coverage their activities receive. Thus, strategic management of these informal relationships will sometimes decisively condition the frame of news and make it converge with their interests and ideological positions.

The benefit when there is a good relationship is that you always have more chances of your information reaching publication and [being] published in the sense that you want or that you have expressed. If there is a bad relationship it may influence negatively. (Politician 10)

\section{Imbalance in informal relationships and derivative risks}

Despite the potential benefits of balance and autonomy, the obtained results show a very different professional reality of informal relationship between journalists and politicians as follows: The use of positions of power and efforts at control is the usual dynamic of their interactions. In this sense, a significant group of actors clearly underlines the usual imbalance in which they interact, and there are two key factors that clearly determine the balance of power between them as follows: the hierarchical position of the actors and their previous careers. 
The two are never equals. There are cases in which the journalist is in a position of superiority by the concrete situation that can happen in a given moment, and conversely also in favour of the politician. (Journalist 18)

Specifically, from these considerable difficulties regarding the balanced development of informal relationships, the following two types of risks or potential negative consequences are identified: professional and those linked to the wider political and democratic environment.

\section{Identifying professional risks: loss of independence and unwanted leaks}

Among the risks associated with the professional sphere, both journalists and politicians understand that the most important danger inherent in their personal affinity relationships is a loss of objectivity and professional independence by both parties.

The risk of loss of impartiality. Things are different from a microscope view, so when you meet people, you know their thoughts... sometimes that can make you lose some perspective. (Politician 15)

Additionally, the interviews identify a key factor in the consequences of the informal relationships between the following two groups: A majority of journalists acknowledge a weaker but significant risk of seeing their autonomous professional position compromised or even subordinated to the partisan interests of political actors.

Personal relationships (with the politicians) are key to keeping the sources, but sometimes exceeded, making it very difficult to distinguish from the professionals. This is bad for readers, listeners ... for everyone. The important thing is to draw the line, and there we have a way to go yet. (Journalist 5)

As for the journalists, they clearly denounce several negative consequences of this type of personal closeness with political actors as follows: operational difficulties in reporting certain controversial topics or problems with the exercise of journalistic criticism of people with whom one has a personal affinity. In short, these instances show significant risks of polluting the information delivered in terms of plurality and balance of sources or in employing objective and rigorous interpretive frames.

The risk is to be conditioned on the time of reporting. That is a huge danger. There is a very high risk that friendship or complicity with a person may condition your reports. (Journalist 15)

Regarding risks, there may be a compromise that may result in excessive contamination of the message. (Journalist 7 )

Finally, political actors also indicate a professional risk derived from personal affinity with journalists. In this regard, it is emphasized that trust and closeness in their relationships can also create an enabling environment for mistakes or indiscretions, possibly resulting in offering sensitive information in a completely involuntary context. Additionally, this type of unwanted leak is a serious problem if the rules of "off the record" are not respected. 
The risks are few, but they exist. For example, a personal relationship with a journalist can lead to saying things that can then be used (off the record), and in fact are used. (Politician 7)

\section{Democratic risks: concern about limiting the public agenda}

From a broader perspective of social and democratic implications, both political actors and the media agree that two risks arise from their personal affinity that can affect the process of forming public opinion. The first is the removal of relevant issues from the media agenda. In this sense, journalism risks becoming an ideological tool that hides or distorts issues critical to the citizenry, thus failing in one of its core regulatory functions.

The risk is that citizens don't have access to public information to which you have all the right. (Journalist 6)

In general, we can speak of a dangerous friendship for both, more to the professionalism / objectivity of the journalist, but especially dangerous for society (...) because a relationship of excessive closeness and proximity easily results in loss of objectivity on the part of the journalist and the weakening of the role of counter power. (Politician 2)

Moreover, some journalists recognize a second serious consequence caused by their close relationships with political power as follows: Building informative speech focuses more on political disputes and partisan tensions than on the interests of citizens. Based on the intensity of their interactions and the convergence of mutual interests, they complained that, in recent decades, political journalism has been devoting too much time and attention to institutional elites and is gradually forgetting to give voice to citizens and independent experts.

A media-political environment in which journalists and politicians fraternize too much easily leads to the formation of what might be called a 'political-media complex' where politicians feed off their disputes through statements, encouraged by journalists, who stop to reflect and analyse the 'reality-of-the-things' that affect the citizens and the public space, to build a political reality that does not connect with the facts or with the interests of the people. (Politician 2)

This worrisome professional bubble of a referential nature is a double risk for political journalism prevented from examining current issues critically and feeds information circuit consumption among elites that is irrelevant to citizens.

Journalists and politicians live in the same bubble. (...) Neither journalists nor politicians tread the road, and fall into the mistake of forgetting the citizen. Journalists have the bad habit of writing to politicians, when we should write to citizens. That is a widespread problem. (Journalist 13)

Table 3. Summary of results on the professional consequences of their informal relations

\begin{tabular}{|l|l|}
\hline \multicolumn{2}{|c|}{ Main perceptions detected } \\
\hline 1. Significant benefits & - Respect and balance as decisive factors to tap \\
& synergies and limit possible excesses of power \\
& - For journalists, access to exclusive information \\
\hline
\end{tabular}




\begin{tabular}{|l|l|}
\hline & $\begin{array}{l}\text { - For politicians, increasing and improving the } \\
\text { media coverage of their activities }\end{array}$ \\
\hline 2. Some worrisome risks & $\begin{array}{l}\text { - For journalists, loss of independence } \\
\text { - For politicians, unwanted information leaks }\end{array}$ \\
\hline 3. Potential democratic risks & $\begin{array}{l}\text { - Limitations on media function as control on } \\
\text { political power (watchdog) } \\
\text { - Reduction of the presence of controversial } \\
\text { issues for political power in the media agenda } \\
\text { - As a result, withdrawal of citizens' interest }\end{array}$ \\
\hline
\end{tabular}

\section{Conclusions}

The results indicate that personal affinity currently plays an important role in relationships between journalists and politicians. The interviews reveal the existence of a euphemistic discourse about this affinity. Both groups intentionally participate for the most part, cataloguing their interactions under the label of "professional". However, both also recognize the implicit and latent form of the decisiveness of the informal contacts. This dual discourse is a result of the weight of the normative values of journalism to establish and maintain distance from the information source to ensure proper adherence to professional standards of news making. Therefore, journalists, in particular, initially try to hide or ignore its existence but later assert its influence in contacts with politicians. This finding is an original contribution of this research.

The main cause of the weight and relevance of this affinity is linked to the mutual need that governs the relationship between journalists and politicians as described in the literature (Blumler and Gurevitch, 1995). The personal affinities and informal relationships arise from two facts. On the one hand, both actors often share spaces because their professional routines impose narrow and regular contacts. On the other hand, both sides have shared interests in terms of influencing the public agenda. Personal relationships are inherent and unavoidable, and their dynamics are impossible to escape. These results support such previous studies as Mancini (1993) and Albæk and colleagues (2014).

Another contribution of this research is the finding not only of the existence of personal affinity but also of its high degree of influence on interactions between journalists and politicians. This key element determines, in both positive and negative ways, the relationship between these actors. Despite the high incidence of this affinity, the results also show that there are factors limiting its action as perceived by the actors involved; in particular, the three professional factors are the strength of the media business, the professional ethics and the dynamics associated with news production routines (for example, the contrast between sources). The presence of these aspects can act as a check on the influence of affinity in the relationships, highlighting or reducing their effects. Identifying these factors is a novel contribution to the literature on this topic. Both journalists and politicians recognize that mutual respect and balance are two factors essential to the establishment and maintenance of informal relationships. If these conditions are met, the two actors believe that affinity can build a more fruitful working professional context for both sides. Personal affinities functioned well as a basic element of a model of cooperation and exchange as suggested by Nimmo (1964) in the 1960s. If these conditions are not respected, it is impossible to maintain personal closeness because journalists' professional autonomy is reduced. In these cases, the elements of confrontation are put in place; distrust and cynicism in the interactions between journalists and politicians increase significantly as Brants and colleagues (2010) have indicated. 
Therefore, for affinity to act as a mechanism that promotes a healthy symbiosis beneficial to democracy, it is necessary to provide sufficient "manoeuvring space" (Larsson, 2002).

The results confirm that the professionalization of political communication, which involves an increase in formal relations (Nimmo, 1964), has not eliminated the incidence of informal exchanges between journalists and politicians. Professionalization has been redirected towards more discreet and less visible relationships but does not eliminate them. Even for political actors, personal closeness is a valuable tool for news management to achieve favourable media coverage and condition both the agenda and the media frame. This conditioning generates not only negative effects as the normative model affirms (Casero-Ripollés et al., 2014; Van Aelst and Aalberg, 2011) but also positive effects. In this line, the findings indicate that personal contacts can bring benefits to both journalists and politicians. Initially, access to more and better information can be provided, especially scoops. Thus, journalists can improve their information products and differentiate themselves from other media, obtaining an extra factor of competitiveness. These results make a new contribution to the previous literature. Additionally, better access to sources can facilitate the development of higher-quality news, thus accomplishing key journalistic functions. Meanwhile, for political actors, informal relationships allow increasing and improving the type of media coverage received to improve politicians' communication management from a strategic perspective. These findings support previous studies, such as that by Tedesco (2011).

However, affinity also comes with risks to the relationship between journalists and politicians. The results of this investigation identified the following two types of risks: democratic and professional. Among the latter, personal affinities may cause loss of objectivity and professional autonomy for journalists. Informal relationships could be associated, in this way, with a danger of subordinating political journalists. Personal closeness could lead to dependence and imbalance. Meanwhile, this proximity could generate important problems for politicians who assume the risk of making mistakes or of carelessness. A significant risk would be inadvertently providing sensitive information to the media, generating unwanted leaks, as Van Aelst and Aalberg suggested (2011). Finally, democratic risks materialize in two ways. The elimination of important issues from the media agenda, especially issues uncomfortable for policymakers, builds an informative discourse focused on the political debate and away from citizen interests. This finding is an important and new contribution to this research field and links personal affinity with the construction of the media agenda and the agenda-setting process. The relationship between journalists and politicians thus contributes to generate a self-referential bubble in which the news is oriented only towards the consumption of political and journalistic elites.

These results offer new evidence on the relationship between journalists and political actors in Spain, which can be applied to other countries of the polarized pluralist model (Hallin and Mancini, 2004). However, this application to polarized pluralist model countries is also a limitation because it will be necessary to extend the analysis of the role of personal affinity in political journalism to other countries and specifically to perform crossnational comparisons among different media systems. This line of research is suggested. Another avenue to enhance and expand this research topic with newer studies is longitudinal analysis, which will permit examining the temporal evolution of the role of personal affinities in interactions between journalists and politicians. This will advance even further the knowledge of this topic relevant to the field of journalism.

\section{Funding}

The author(s) disclosed receipt of the following financial support for the research, authorship, and/ or publication of this article: This article is part of the research project 
CSO2014-52283-C2-1-P funded by the Spanish Ministry of Economy and Competitiveness.

\section{References}

Albæk E, Van Dalen A, Jabil N and de Vreese C (2014) Political Journalism in Comparative Perspective. Cambridge, UK: Cambridge University Press.

Altheide DL and Snow RP (1979) Media Logic. Beverly Hills, CA: Sage.

Berganza R, Van Dalen A and Chaparro MA (2010) La percepción mutua de las relaciones entre periodistas parlamentarios y miembros del congreso y de su influencia en las agendas política y mediática. Revista de Comunicación 9: 7-25.

Brants K, de Vreese C, Möller J and Van Praag Ph (2010) The real spiral of cynicism? Symbiosis and mistrust between politicians and journalists. The International Journal of Press/Politics 15(1): 25-40.

Blumler JG and Gurevitch M (1995) The Crisis of Public Communication. London, UK: Routledge.

Casero-Ripollés A (2008) Modelos de relación entre periodistas y políticos: la perspectiva de la negociación constante. Estudios sobre el Mensaje Periodístico 14: 111-128.

Casero-Ripollés A (2012) El periodismo político en España: algunas características definitorias. In: Casero-Ripollés A (ed.) Periodismo Político en España: Concepciones, Tensiones y Elecciones. La Laguna, España: Sociedad Latina de Comunicación Social, pp. 19-46.

Casero-Ripollés A and López-Rabadán P (2014) Media engagement boundaries and political influence in Europe. American Behavioral Scientist 58(7): 859-868.

Casero-Ripolles A, García-Santamaría J V and Fernández-Beaumont J (2015) The politicisation of journalism in Spain: Three obstacles to the professional autonomy of journalists. Anàlisi 53: 95-109.

Casero-Ripollés, A, Feenstra, R A, and Tormey, S (2016). Old and New Media Logics in an Electoral Campaign: The Case of Podemos and the Two-Way Street Mediatization of Politics. International Journal of Press/Politics 21(3): 378-397.

Casero-Ripollés A, Izquierdo-Castillo J, and Doménech-Fabregat H (2014) From watchdog to watched dog: oversight and pressures between journalists and politicians in the context of mediatization. Trípodos 34: 23-40.

Cook TE (2005) Governing with the News. The News Media as a Political Institution (2nd ed.). Chicago, IL: University of Chicago Press.

Davis A (2007) Investigating journalist influences on political issue agendas at Westminster. Political Communication 24(2): 181-199.

Delli Carpini MX (1994) Critical symbiosis: three themes in president-press relations. Media Studies Journal 8(2): 185-197. 
Esser F, Strömbäck J, and De Vreese C. (2012) Reviewing key concepts in research on political news journalism. Journalism 13(2): 139-143.

Gans HJ (1979) Deciding What's News: A Study of CBS Evening News, NBC Nightly News, Newsweek, and Time. New York, NY: Pantheon.

Gans HJ (2003) Democracy and the News. Oxford, UK: Oxford University Press.

Hallin DC and Mancini P (2004) Comparing Media Systems: Three Models of Media and Politics. Cambridge, UK: Cambridge University Press.

Hanitzsch, T, and Mellado, C (2011). What Shapes the News around the World? How Journalists in Eighteen Countries Perceive Influences on Their Work. The International Journal of Press/Politics 16 (3): 404-426.

Lang GE and Lang K (1981) Watergate: an exploration of the agenda-building process. Mass Communication Review Yearbook 2: 447-468.

Larsson L (2002) Journalists and politicians: a relationship requiring manoeuvring space. Journalism Studies 3(1): 21-33.

Mancini P (1993) Between trust and suspicion: how political journalists solve the dilemma. European Journal of Communication 8(1): 33-51.

Maurer P and Pfetsch B (2014) News coverage of politics and conflict levels: a crossnational study of journalists' and politicians' perceptions of two elements of mediatization. Journalism Studies 15(3): 339-355.

Mazzoleni G and Schutz W (1999) Mediatization of politics: a challenge for democracy? Political Communication 16(3): 247-261.

McCombs, M, Holbert, R L, Kiousis, S, and Wanta, W (2011). The news and public opinion. Media effects on civic life. Cambridge: Polity Press.

Mellado C (2014) Professional roles in news content: Six dimensions of journalistic role performance. Journalism Studies DOI: 10.1080/1461670X.2014.922276

Neveu E (2002) Four generations of political journalism. In: Kuhn R and Neveu E (eds) Political Journalism: New Challenges, New Practices. London, UK: Routledge, pp. 22-43.

Nimmo DD (1964) Newsgathering in Washington: A Study in Political Communication. New York, NY: Atherton Press.

Rosenstiel T (1993) Strange Bedfellows, How Television and the Presidential Candidates Changed American Politics 1992. New York, NY: Hyperion.

Sampedro V and Seoane F (2008). The 2008 Spanish general elections: 'antagonistic bipolarization' geared by presidential debates, partisanship, and media interests. The International Journal of Press/Politics 13(3): 336-344. 
Sellers, P (2010). Cycles of spin: Strategic communication in the US Congress. New York: Cambridge University Press.

Strömbäck $J$ and Esser $F$ (2014) Mediatization of politics: towards a theoretical framework. In: Esser $\mathrm{F}$ and Strömbäck J (eds) Mediatization of Politics. Understanding the Transformation of Western Democracies. Basingstoke, UK: Palgrave Macmillan, pp. 3-28.

Strömbäck J and Van Aelst P (2013). Why political parties adapt to the media: exploring the fourth dimension of mediatization. International Communication Gazette 75(4): 341-358.

Tedesco JC (2011) Political public relations and agenda building. In: Strömbäck $J$ and Kiousis S (eds) Political Public Relations: Principles and Applications. London, UK: Routledge, pp. 75-94.

Van Aelst P and Aalberg T (2011) Between trust and suspicion. A comparative study of the relationship between politicians and political journalists in Belgium, Norway and Sweden. Javnost-the Public 18(4): 73-88.

Van Aelst P, Brants K, Van Praag Ph, de Vreese C, Nuytemans M and Van Dalen A (2008) The fourth estate as superpower? An empirical study of perceptions of media power in Belgium and the Netherlands. Journalism Studies 9(4): 494-511.

Van Dalen A, Albæk E and de Vreese C (2011) Suspicious minds: explaining political cynicism among political journalists in Europe. European Journal of Communication 26(2): 147-162.

Van Dalen A (2012) The people behind the political headlines: a comparison of political journalists in Denmark, Germany, the United Kingdom and Spain. International Communication Gazette, 74(5), 464-483.

Van Dalen A, De Vreese C and Albæk E (2012) Different roles, different content? A fourcountry comparison of the role conceptions and reporting style of political journalists. Journalism 13(7): 903-922.

Walgrave, S (2008). Again, the almighty mass media? The media's political agenda-setting power according to politicians and journalists in Belgium. Political Communication 25(4): 445-459.

Wolfsfeld, G (2011). Making Sense of Media \& Politics. New York: Routledge. 